\title{
Faktor-Faktor Yang Mempengaruhi Pemindahan Pusat Ibukota Kabupaten Bima Provinsi Nusa Tenggara Barat
}

\author{
Muh. Zulfiqri Syahmat \\ piki.syahmat@gmail.com \\ Sekolah Tinggi Ilmu Administrasi (STIA) Mataram
}

\begin{abstract}
ABSTRAK
Berdasarkan pada pokok permasalahan, maka tujuan penelitian ini adalah mengetahui dan memahami serta menganalisis bagaimana proses pemindahan Ibukota Kabupaten Bima serta menganalisis faktor-faktor yang mempengaruhi pemindahan pusat Ibukota Kabupaten Bima. Dalam penelitian ini peneliti mengambil metode penelitian Kualitatif, dimana lokasi dalam penelitian ini di lakukan di Pemerintah Kabupaten Bima, Nusa Tenggara Barat. Pengumpulan data dalam penelitian ini menggunakan Observasi, interview dan dokumentasi. Hasil penelitian Dalam pengimplemantasian pemindahan pusat ibukota dan pembangunan ibukota Kabupaten Bima di lokasi yang baru sedang dalam proses pembangunan insfrastruktur dari 43 Organisasi Perangkat Daerah hanya 6 OPD yang sudah berada pada lokasi pusat pelayanan pemerintah Kabupaten Bima Dari latar belakang pemindahan pusat ibukota kabupaten bima yang melatar belakangi penghambatan pemindahan pusat ibukota Kabupaten Bima adalah faktor anggaran, dimana dana yang digunakan dalam pembangunan infrastruktur adalah hanya bersumber dari APBD. Dari kelima (5) faktor yang mempengaruhi pemindahan ibukota Kabupaten Bima yaitu faktor letak geografis, faktor kependudukan, faktor kebijakan pemerintah, faktor politik dan faktor historis/sejarah sudah berjalan dengan baik artinya mendukung dan mempengaruhi percepatan pemindahan pusat ibukota Kabupaten Bima.
\end{abstract}

Kata Kunci: Pemerintah Daerah; Faktor-Faktor; Pemindahan; Ibukota.

\begin{abstract}
Based on the subject matter, the purpose of this study is to know and understand and analyze how the process of transfer of the Capital District of Bima and analyze the factors that affect the transfer of the center of the Capital District of Bima. In this study the researchers took Qualitative research method, where the location in this study was conducted in the Government of Kabupaten Bima, West Nusa Tenggara. Data collection in this study using observation, interview and documentation. Result of research In implementation displacement center of capital and development capital of Regency of Bima in new location is in process of development of infrastructure of 43 Organization of Regional Device only 6 OPD already located at central government service location of Regency of Bima From background of transfer center of capital of regency of bima which background inhibition of transfer of capital center of Bima Regency is budget factor, where fund used in infrastructure development is only sourced from APBD. From the fifth (5) factors that affect the transfer of the capital city of Bima Regency, namely geographical location, population factor, government policy factor, political factor and historical / historical factors have been running well, it means supporting and influencing acceleration of transfer center of Bima regency capital.
\end{abstract}

Keywords: Local Government; Factors; Removal; Capital city. 


\section{PENDAHULUAN}

Pemekaran wilayah diyakini dari sebagian pihak menjadi salah satu alternative bagi masyarakat untuk mempercepat proses penyejahteraan diri. Sejak diimplementasikannya UndangUndang Nomor 22 tahun 1999 yang kemudian diganti dengan Undang-Undang Nomor 32 tahun 2004 berimplikasi terhadap munculnya berbagai keinginan masyarakat di daerah untuk memekarkan diri, salah satunya adalah terbentuknya Pemerintah Kota Bima yang dimekarkan dari pemerintahan induk yakni Pemerintah Kabupaten Bima sekitar tahun 2002 silam melalui Undang-Undang Nomor 13 tahun 2002.

Kabupaten Bima merupakan salah satu Daerah Otonom di Provinsi Nusa Tenggara Barat, terletak di ujung timur dari Pulau Sumbawa bersebelahan dengan Kota Bima (pecahan dari Kota Bima). Berbagai ekspetasi rakyat untuk hidup lebih sejahtera dari masa-masa sebelumnya mulai bermunculan. Diikuti dengan lonjakan pelaksanaan berbagai program dan terobosan pembangunan sebagai sebuah wujud pemenuhan aspek kebutuhan rakyat dalam berbagai bidang guna perbaikan taraf kehidupan masyarakatnya. Dibalik berbagai upaya pada dua pemerintahan ini dalam melakukan terobosan pembangunan bagi masyarakatnya. Masih terselip satu persoalan krusial yang masih menggelayut diantara keduanya yang perlu segera diselesaikan bersama yakni permasalahan menyangkut pemindahan Ibukota Kabupaten Bima ke wilayah Kecamatan Woha serta pembagian dan penyerahan asset daerah yang masih dikuasai oleh Kabupaten Induk.

Pemerintahan pada masa sekarang memiliki fungsi diantaranya memberikan pelayanan sesuai dengan aturan hukum yang berlaku dan memberikan pelayanan publik yang baik dan optimal (Rieseneder, 2008). Optimalisasi proses dan pelayanan (service and process optimization) merupakan salah satu komponen untuk mewujudkan pemerintah yang baik (good government) (Michigan Lean Consortium, 2013).

Alasan pemindahan ini dikarenakan beberapa faktor, yakni faktor strategi militer, informasi keamanan negara, Naypyitaw merupakan daerah yang lebih mudah dikontrol, faktor dekolonisasi, upaya untuk mengisolasikan pusat pemerintahan dari jumlah penduduk yang besar, dan untuk mengikuti kepercayaan trandisional Myanmar (Myoe, 2006). 


\section{LANDASAN TEORI}

\section{A. Konsep Pemerintahan Daerah}

Pemerintahan juga diartikan kekuasaan legislatif, eksekutif, dan yudikatif atau kelengkapan negara yang bisa bertindak untuk nama negara. Sedangkan pemerintah pada arti sempit (bestuurvoering), yaitu mencakup fungsifungsi organisasi yang menjalankan suatu tugas pemerintahan. Titik beratnya pemerintahan dalam arti yang sempit ini hanya saja berkaitan dengan kekuasaan yang bisa menjalankan fungsi eksekutif saja (Sadjijono. 2008)

Kehadiran pemerintahan dan keberadaan pemerintah adalah sesuatu yang menjadi keharusan bagi proses kewajiban dalam kehidupan masyarakat. Sejarah telah membuktikan bahwa masyarakat, sekecil apa pun kelompoknya, bahkan sebagai individu sekalipun, membutuhkan pelayanan pemerintah. Oleh karena itu kehidupan sehari-hari erat hubungannya dengan fungsi-fungsi pemerintah di dalamnya. (Sarundajang, 2003:5)

Pemerintahan adalah Besctuurvoering atau pelaksanaan tugas pemerintah, sedangkan Pemerintah adalah organ/alat atau alat yang menjalankan pemerintahan (Ridwan, 2014). Pemerintahan adalah sebagai alat kelengkapan negara dapat diartikan secara luas dan dalam artis sempit. Pemerintahan dalam arti luas mencangkup semua alat kelengkapan negara, yang terjadi dari cabang-cabang kekuasaan eksekutif, legislatif dan yudisial atau alat-alat kelengkapan negara lain yang bertindak untuk dan atas nama negara.

\section{B. Pembentukan wilayah}

Rustiadi，dkk，(2009) "Wilayah didefinisikan sebagai unit geografis dengan batas-batas yang spesifik (tertentu), dimana bagian -bagian dari wilayah tersebut (sub wilayah) satu sama lain saling berinteraksi secara fungsional. Istilah wilayah mengacu pada pengertian unit geografis, dalam hal ini wilayah didefinisikan sebagai suatu unit geografis dengan batas-batas tertentu dimana komponen-komponen di dalamnya memiliki keterkaitan dan hubungan fungsional satu dengan yang lainya".

Dari definisi tersebut tidak ada batasan spesifik dari suatu wilayah. Batasannya lebih bersifat "meaningful" untuk perencanaan, pelaksanaan, monitoring, pengendalian maupun evaluasi. Menurut Tukiyat (2002), "konsep pengembangan ekonomi wilayah harus berorientasi pada pertumbuhan ekonomi wilayah dengan menggali potensi produk unggulan daerah. Salah satu aspek yang perlu diperhatikan dalam kegiatan 
pengembangan wilayah adalah menyusun perencanaan wilayah".

Menurut Hamid (2008), ada beberapa faktor dan indikator untuk menentukan lokasi atau wilayah calon ibukota kabupaten yaitu meliputi:

a) Faktor lingkungan makro adalah dorongan lingkungan baik dari dalam maupun dari luar.

b) Faktor endowment daerah yaitu ketersediaan SDM yang memadai dan SDA yang potensial.

c) Faktor budaya yang meliputi sifat dan perilaku masyarakat, adat istiadat yang memberikan dukungan terhadap penetapan ibukota kabupaten.

\section{Faktor Lokasi Ibukota dan Pusat Pemerintahan}

Menurut Siong (2006), Putra jaya dipilih sebagai lokasi pusat pemerintahan Malaysia yang baru dikarenakan beberapa faktor, yakni: (1) ketersediaan lahan yang masih cukup dan kalkulasi biaya infrastruktur yang lebih rasional, (2) lokasi strategis yang berada pada koridor pertumbuhan, (3) aksesibilitas yang baik dan jaringan transportasi, (4) jenis dan kerapatan vegetasi yang dapat mendukung kebijakan, (5) bentuk lahan, dan (6) dampak minimum terhadap masyarakat lokal.
Syarief (2013) menjelaskan bahwa terdapat beberapa faktor yang dapat mempengaruhi pemilihan lokasi dan perkembangan sebuah kota, yakni faktor geografis, jenis tanah, ketersediaan air, spekulasi tanah, keberadaan fasilitas, aksesibilitas, jumlah dan kepadatan penduduk, kebijakan perkotaan, pendapatan penduduk, dan keberadaan industri.

Beberapa faktor prasyarat dalam pembentukan daerah baru sesuai dengan Peraturan pemerintah No. 78 Tahun 2007 diantaranya ialah kemampuan ekonomi, potensi daerah, keadaan sosial budaya, kependudukan, luas daerah, pertahanan, keamanan, kemampuan keuangan, dan tingkat kesejahteraan masyarakat.

Ali (2010) mengemukakan beberapa faktor yang mempengaruhi pemilihan lokasi pusat pemerintahan, yakni : (1) letak geografis yang strategis dan berada pada dataran rendah $(<3 \%)$, (2) ketersediaan lahan yang cukup, (3) penggunaan lahan yang bukan lahan pertanian, (4) status lahan, (5) bukan daerah rawan bencana, (6) ketersediaan sumberdaya air yang memadai, (7) aksesibilitas yang baik, (8) jumlah penduduk, (9) kepadatan penduduk, (10) heterogenitas masyarakat (ekonomi, agama, etnis), dan (11) ketersediaan fasilitas ekonomi dan sosial (rumah sakit, 
air bersih, jaringan telepon, jaringan listrik).

\section{Pemindahan Ibukota}

Fungsi-fungsi yang berada dalam sebuah ibukota mencakup fungsi Ekonomi, fungsi Sosial, dan fungsi Pemerintahan. Claval (2000) mengungkapkan pula bahwa kajian mengenai ibukota juga banyak dikaji oleh geograf, dimana pada ilmu geografi ibukota difokuskan pada pengertian sebuah tempat yang memiliki jumlah individu yang tinggi, tradisi yang kuat, wilayah dengan peninggalan historis dan monumen yang mencolok, serta wilayah tersebut terkadang memiliki nilai yang tinggi.

Sejalan dengan pengertian yang diutarakan oleh Claval, Wusten (2000) juga mengungkapkan bahwa ibukota diartikan sebagai pusat administrasi dan politik yang menjadi simbol kekuasaan yang didalamnya terdapat banyak fungsi dan hierarki yang berbeda, seperti fungsi pelayanan, fungsi agama, fungsi pemerintahan, dan fungsi militer. Dalam hal ini Qi (2008) juga mendefinisikan bahwa pada mulanya ibukota dibangun sebagai sebuah simbol dari lahirnya atau berdirinya sebuah wilayah dan juga sebagai sebuah simbol peradaban.

Di Indonesia, kawasan perkotaan dibedakan berdasarkan status administrasinya, yakni : a. Kawasan perkotaan berstatus administratif daerah kota;

b. Kawasan perkotaan yang merupakan bagian dari daerah kabupaten;

c. Kawasan perkotaan baru yang merupakan hasil pembangunan yang mengubah kawasan perdesaan menjadi kawasan perkotaan; dan

d. Kawasan perkotaan yang merupakan bagian dari dua atau lebih daerah yang berbatasan (Tarigan, 2006).

\section{METODE PENELITIAN}

Dalam penelitian ini peneliti mengambil metode penelitian Kualitatif, dimana lokasi dalam penelitian ini di lakukan di Pemerintah Kabupaten Bima, Nusa Tenggara Barat. Pengumpulan data dalam penelitian ini menggunakan Observasi, Metode Observasi atau pengamatan adalah alat pengumpulan data yang dilakukan dengan cara mengamati dan mencatat secara sistematik gejalagejala yang tampak pada objek penelitian (Margono, 1997).

Pengamatan dan pencatatan ini dilakukan terhadap objek ditempat terjadi atau berlangsungnya peristiwa. Menurut Nasution dalam Sugiyono (2014) Observasi adalah dasar semua pengetahuan. Observasi dilakukan pada Pemerintah Kabupaten Bima.

Esterberg dalam Sugiyono (2014; 72) teknik wawancara ialah, merupakan 
pertemuan dua orang untuk bertukar informasi dan ide melalui tanya jawab, sehingga dapat dikontruksikan makna dalam suatu topik tertentu. Peneliti tidak menggunakan koesioner dalam melakukan proses wawacara, namun menyiapkan sebuah tema besar peranan kepada sumber data. Pertanyaan akan terus melebur berdasarkan proses wawancara sampai didapat informasi yang dibutuhkan.

Wawancara dilakukan dengan Bupati Bima dan Wakil Bupati Bima, Ka. BAPPEDA Kab. Bima, KABAG Pemerintahan, Ketua DPRD Kabupaten Bima, CAMAT Setempat dan LSM Setempat. Menurut (Arkunto, 2006) dokumentasi adalah mencari data mengenai hal-hal atau variabel yang berupa catatan, transkip, agenda, buku, surat kabar, majalah dan sebagainya. Pencarian data dalam penelitian kualitatif juga dapat dlakukan tanpa harus melalui sumber data langsung.

\section{HASIL DAN PEMBAHASAN}

Sebelum peneliti membahas hasil penelitian pada faktor-faktor yang mempengaruhi pemindahan ibukota Kabupaten Bima, ada beberapa temuan/konsep penelitian dari penelitian terdahulu dan dasar perbedaan penelitian peneliti yaitu, Penelitian yang di lakukan oleh Nuristi, Dinartika Arneda tahun (2015) dengan judul Implementasi
Kebijakan Pengembangan Wilayah melalui Pemindahan Ibukota Kabupaten Madiun ke Wilayah Mejayan (Studi pada Badan Perencanaan Pembangunan Daerah Kabupaten Madiun) dengan Hasil penelitian menunjukkan bahwa pelaksanaan pemindahan ibukota ke Wilayah Mejayan telah memperhatikan aspek penting keberhasilan suatu implementasi kebijakan walaupun dilakukan secara bertahap.

Sedangkan pengembangan wilayah ditinjau aspek strategis, teknis dan administratif telah berjalan dengan baik. Rekomendasi penting yang dapat diberikan dari hasil penelitian ini adalah bagi Pemerintah Kabupaten Madiun khususnya Badan Perencanaan Pembangunan Daerah Kabupaten Madiun untuk mempercepat proses pembangunan di Wilayah Mejayan, perlu adanya sosialisasi terkait pemetaan geospasial, dukungan anggaran yang memadai dan konsistensi pengaturan zonasi.

Perbedaan penelitian penulis dengan penelitian di atas adalah terletak pada permasalah yang begitu kompleks dari penelitian di atas menunjukan aspek penting keberhasilan suatu implementasi dalam suatu pemindahan ibukota wilayah kabupaten, sedangkan dalam penelitian penulis meneliti dalam konteks masalah faktor yang mempengaruhi pemindahan 
ibukota kabupaten serta menimbulkan pertanyaan besar dalam penelitian penulis yaitu mengapa terjadi faktor keterlambatan dalam proses pemindahan ibukota kabupaten.

Selanjutnya penelitian yang di lakukan oleh Azahra, Ma'arif (2016) dengan judul Alternatif Pengembangan Kecamatan Sape Sebagai Pusat Kegiatan Dibagian Timur Kabupaten Bima, NTB, dengan metode penelitian Analisis Kualitatif Deskriktif dengan dibantu analytical hirarchi process (AHP) dengan hasil Dengan posisi Kabupaten Bima bagian timur dan barat yang di tengahtengahnya adalah wilayah pemerintahan Kota Bima, mengakibatkan jangkauan pelayanan semakin jauh dan biaya transport semakin meningkat, sehingga proses aglomerasi akan terjadi dengan sendirinya.

Alternatif Kecamatan Sape dapat dijadikan sebagai titik pusat DOB sudah cukup sesuai dengan melihat kondisi saat sekarang dan kedepannya. Berdasarkan dari kesiapan sarana prasarana dan fasilitas fisik, serta kemampuan ekonomi wilayah di bantu dengan kesiapan dari segi aksesibilitas yang sudah sebagian baik, keberadaan pelabuhan laut.

Perbedaan Penelitian penulis yang sangat mendasar adalah terletak pada hasil yang akan dicapai dalam hal ini penulis mencari dan mengetahui apa saja faktorfaktor yang mempengaruhi pemindahan pusat ibukota Kabupaten Bima baik yang nantinya hasil yang di capai adalah berupa faktor pendukung dan faktor penghambat. Sedangkan dalam penelitian di atas di fokuskan hasil kebutuhan primer.

Sehingga hasil penelitian pada proses pemindahan dan faktor-fakor yang mempengaruhi pemindahan pusat ibukota Kabupaten Bima baik dari faktor letak geografis, faktor kependudukan, faktor kebijakan pemerintah, faktor politik maupun faktor historis atau sejarah pemindahan pusat Ibukota Kabupaten Bima. Pada bab ini peneliti lebih banyak menggunakan data wawancara dengan aktor-aktor pemerintah daerah Kabupaten Bima yang di pilih secara tepat dalam menjawab persoalan-persoalan pemindahan pusat Ibukota Kabupaten Bima.

Upaya pemerintah Kabupaten Bima dalam mempercepat pemindahan pusat Ibukota Kabupaten Bima sudah melalui berbagai upaya namun berbagai persoalan sosial di berbagai wilayah juga harus di lebih diperhatikan karena issu yang berkembang di tatanan masyarakat Kabupaten Bima saat ini masih terkait degan issu kemiskinan. Tidak hanya terjadi di wilayah Kabupaten Bima namun juga menjadi dampak perkembangan ekonomi 
nasional di berbagai wilayah-wilayah di indonesia

\section{A. Proses Pemindahan Pusat Ibukota}

\section{Kabupaten Bima.}

1. Pusat pemerintahan Ibukota Kabupaten Bima.

Mengenai pemindahan pusat Ibukota Kabupaten Bima sudah menjadi arah gerak pemerintah Kabupaten Bima sesuai dengan Peraturan Pemerintah Republik Indonesia Nomor 31 Tahun 2008 Tentang pemindahan ibukota Kabupaten Bima dari Raba Kota Bima ke Kecamatan Woha Kabupaten Bima. Kota Bima ini wilayahnya berasal dari sebagian wilayah Kabupaten Bima yang antara lain Raba termasuk dalam wilayah Kota Bima. Dengan masuknya Raba menjadi bagian dan Kota Bima maka ibu kota Kabupaten Bima yang berlokasi di Raba wilayah Kota Bima perlu dipindah ke wilayah Kabupaten Bima.

Sehubung dengan hal tersebut, sebagai konsekuensi lahirnya kebijakan pembentukan Kota Bima melalui undangundang No 13 Tahun 2002, maka untuk efektifnya penyelenggaraan tugas-tugas pemerintahan, dan percepatan pembangunan pusat-pusat pertumbuhan baru, pemerintah Kabupaten Bima telah menyusun Rencana Tata Ruang Ibukota Kabupaten Bima dengan membagi struktur ruang pusat pertumbuhan kota Kabupaten
Bima dalam 3 (tiga) bagian wilayah kota, yakni Desa Dadibou sebagai pusat kawasan pemerintahan, Desa Talabiu sebagai kawasan fungsi pendukung dan Desa Daru sebagai kawasan fungsi pelayanan sosial. Hal ini sesuai dengan hasil wawancara dengan Bapak Ian selaku Kabid Admistrasi Pemerintahan Umum daerah Kab. Bima pada hari Kamis tanggal 29 Maret 2018 jam 10:15 adalah sebagai berikut :

"Pemindahan Pusat Pemerintah Kabupaten Bima sedang dalam proses pembangunan, ada 3 Desa bagian wilayah yang difokuskan dalam fokus pertumbuhan pusat ibukota Kabupaten Bima."

Dari hasil wawancara dengan bapak Ian selaku Kabid Administrasi Pemerintahan Umum daerah Kab. Bima dapat di analisis bahwa proses pemindahan pusat ibukota Kabupaten Bima sedang berjalan atau sedang dalam proses pembangunan, dengan kata lain alokasi atau lokasi pusat pelayanan pemerintahan Kabupaten Bima sudah ditetapkan di Kecamatan Woha dan akan memfokuskan pada 3 (tiga) pembangunan kawasan yaitu pertama kawasan pusat pemerintahan, kedua pusat kawasan fungsi pendukung, dan ketiga adalah kawasan pusat fungsi pelayanan sosial. Dimana pusat Ibukota Kabupaten Bima ini berada di salah satu Kecamatan yang ada. 
Upaya pemerintah Kabupaten

Bima dalam mempercepat pemindahan pusat Ibukota Kabupaten Bima sudah melalui berbagai upaya namun berbagai persoalan sosial di berbagai wilayah juga harus di lebih diperhatikan karena issu yang berkembang di tatanan masyarakat Kabupaten Bima saat ini masih terkait degan issu kemiskinan. Tidak hanya terjadi di wilayah Kabupaten Bima namun juga menjadi dampak perkembangan ekonomi nasional di berbagai wilayah-wilayah di indonesia di Kabupaten Bima yaitu Kecamatan Woha.

2. Kebijakan Perkotaan.

Pemindahan pusat ibukota Kabupaten Bima menjadi salah satu bentuk upaya pemerintah Kabupaten Bima dalam meningkatkan pelayanan yang efisien kepada masyarakat dan kebijakan ini juga mengacu pada dasar Surat Edaran Menteri Dalam Negeri No 650/989/IV/Bangda, tanggal 5 Juni 2000, tentang pedoman umum Penyusunan Program Dasar Pembangunan Perkotaan (PDPP)

Berdasarkan Rencana Tata Ruang Wilayah Kabupaten Bima bahwa Kota Woha ditetapkan sebagai Pusat Kegiatan Wilayah Promosi yang mengemban fungsi dengan tingkat pelayanan skala regional dan kabupaten sebagai berikut :

a) Pusat pelayanan Pemerintahan; b) Pusat perdagangan, bisnis, keuangan, dan jasa skala regional dan atau kabupaten;

c) Pusat pelayanan pendidikan dan kesehatan;

d) Pusat pelayanan umum dan sosial skala regional dan atau kabupaten; dan

e) Simpul transportasi.

Berdasarkan arahan Pengembangan Kawasan Peruntukan Pesisir dan pulaupulau kecil dalam RTRW Kabupaten Bima, Kecamatan Woha (Desa Pandai, Donggobolo, Dadibou, Talabiu) merupakan zona yang memiliki Potensi perikanan budidaya (tambak) serta sebagai kawasan minapolitan yang berpusat di Desa Penapali. Potensi lainnya yang terdapat pada wilyah perencanaan adalah tambang Mangan, sehingga menjadikan kota woha sebagai salah satu zona wilayah usaha pertambangan di Kabupaten Bima.

Melirik dari syarat dan proses pemindahan pusat Ibukota Kabupaten Bima tidak terlepas dari unsur Desposisi, struktur birokrasinya, sumber dayanya dan komunikasinya baik dari pemerintah daerah kepada masyarakat atau sebaliknya dari masyarakat terhadap pemerintah daerah Kabupaten Bima, tidak hanya komunikasi pemerintah daerah kepada masyarakat namun pemerintah daerah Kabupaten Bima harus menjaga 
komunikasi yang baik terhadap pemerintah propisi maupun pemerintah pusat. Karena tanpa dukungan pemerintah propinsi dan pusat tidak akan terjalin komunikasi srta pengaruh kepada desposisi yang baik. Dari hasil wawancara dengan Bapak Mansykur S.H. selaku Kabid Fisik dan Prasarana BAPPEDA Kab. Bima pada Hari Rabu tanggal 28 Maret 2018 jam 13:12 mengatakan bahwa.

"Pemerintah Kabupaten Bima, Khususnya bidang Fisik dan Prasarana Bappeda Kab. Bima sudah menjalankan tugas dengan semestinya sesuai dengan Tupoksi nya sendiri. Pemerintah Kabupaten Bima mempunyai Kebijakan dalam pembangunan perkotaan secara yuridis.."

Dari pemaparan bapak Mansykur S.H. selaku Kabid Fisik dan Prasarana BAPPEDA Kab. Bima dapat di analisis bahwa komitmen dari Pemerintah Daerah Kabupaten Bima sudah ada untuk melaksanakan proses pemindahan ibukota Kabupaten Bima dalam rangka mempercepat pembangunan pelaksanaan pemindahan Ibukota Kabupaten Bima. Sebab dalam pemindahan pusat ibukota Kabupaten Bima selanjutnya dari hasil wawancara dengan Bapak A.Rifaid selaku Kabid Tata Ruang Dinas Pekerjaan Umum dan Penataan Ruang sedikit dapat dianalisis bahwa komunikasi yang baik dengan pemerintah terhadap masyarakat sudah terjalin dengan baik dan mendapatkan tanggapan positif dari masyarakat.

\section{B. Faktor-Faktor Yang Mempengaruhi} Pemindahan Pusat Ibukota Kabupaten Bima

\section{Faktor Letak Geografis.}

Pengaruh letak geografis terhadap pemindahan Pusat Ibukota Kabupaten Bima bahwa letak geografis dapat di lihat dari gambaran jarak lokasi pusat pemerintahan yang baru dengan pusat pemerintahan yang lama, serta jarak dengan kota-kota yang ada disekitar lokasi pemilihan pusat Ibukota yang baru. Hal ini nantinya akan sangat menentukan interaksi antara wilayah-wilayah disekitar. Letak geografis Pusat Pemerintahan Kabupaten Bima harus mengacu kepada analisisanalisis AMDAL maupun SWOT karena dalam menentukan lokasi harus melihat jarak kedekatan pelayanan kepada masyarakat bagaimana pelayanan itu bisa semakin dekat dengan masyarakat, sehingga masyarakat bisa mendapatkan pelayanan yang cepat dan tepat, sebab keutaman pemerintah adalah memberikan pelayanan yang baik kepada masyarakat.

Hasil wawancara dengan Bapak Ian selaku Kabid Admistrasi Pemerintahan Umum daerah Kab. Bima pada hari Kamis 
tanggal 29 Maret 2018 jam 10:15 adalah sebagai berikut :

"Peran bagian Administrasi Pemerintahan Umum daerah Kab. Bima hanya menyiapkan lahan sarana dan prasarana melalui sub. Bagian pengadaan tanah dengan urusan RTRW adalah urusan BAPPEDA sedangkan teknis pembangunan adalah urusan Dinas Pekerjaan Umum dan Tata Ruang (DPUTR)."

Dari hasil wawancara dengan bapak Ian selaku Kabid Admistrasi Pemerintahan Umum daerah Kab. Bima dapat di analisis bahwa secara administrasi pemisahan Kabupaten Bima dan Kota Bima sudah tertuang dalam Undangundang Nomor 13 Tahun 2002 sedangkan usulan program pembangunan Ibukota Kabupaten Bima sebagaimana dijabarkan dari kebijakan pembangunan jangka menengah Kabupaten Bima sesuai tertuang dalam RPJMD 2005-2010 dan Peraturan Pemerintah Nomor 31 Tahun 2008 tentang pemindahan Ibukota Kabupaten Bima dari Raba Wilayah Kota Bima ke Kecamatan Woha Kabupaten Bima bahwa pemerintah harus segera mengimplementasikan pemindahan dan pembangunan ibukota Kabupaten Bima di lokasi yang baru.

Jika melihat dari penentuan lokasi pusat Ibukota Kabupaten bima, pemerintah
Kabupaten Bima sudah melewati dan melakukan berbagai pertimbangan yang matang dalam menentukan lokasi pusat ibukota kabupaten, salah satunya adalah membentuk tim pengkaji lokasi ibukota Kabupaten Bima hingga akhirnya Kecamata Woha di tunjuk sebagai pusat Ibukota Kabupaten Bima dengan rumusan hasil seminar sehari tentang lokasi ibukota kabupaten bima di paruga parenta - bima pada sabtu, 17 juni 2006 dengan merumuskan hal-hal sebagai berikut :

1. Penetapan dan pemindahan ibukota kabupaten bima kelokasi yang baru pada prinsipnya bertujuan untuk lebih mengefektifkan jalanya penyelenggaraan pemerintahan dan meningkatkan kualitas pelayanan publik. Oleh karena itu penetapan dan pemindahan ibukota Kabupaten Bima harus berdasarkan kepentingan masyarakat yang lebih besar dan berdimensi jangka panjang dengan berpedoman pada peraturan perundang-undangan yang berlaku, serta sedapat mungkin dihindarkan dari kepentingan-kepentingan pribadi, golongan, kelompok serta kepentingan elit politik yang sifatnya sesaat.

2. Pemindahan ibukota Kabupaten Bima kelokasi baru harus memenuhi 3 syarat utama yaitu : 
a) Aspek normatif (UndangUndang Nomor 32 Tahun 2004 Tentang Pemerintahan Daerah)

b) Aspek teknis (meliputi syarat administratif, teknis dan fisik kewilayahan)

c) Aspek sosial, ekonomi dan politik (antara lain meliputi peningkatan publik service, kebutuhan, antisipasi pengembangan yang akan datang, pengembagan ekonomi, perluasan wilayah, pertumbuhan ekonomi, entitas, kelompok dan multikulturalisme.

3. Kriteria dalam pemindahan ibukota Kabupaten Bima berdasarkan masukan dari narasumber paling tidak harus memperhatikan kriteria/aspek sebagai berikut :
a) Aspek tata ruang
b) Aspek aksesibilitas/keterjangkauan
c) Aspek penduduk
d) Aspek ketersediaan fasilitas
e) Aspek sosial ekonomi dan;
f) Aspek lain yang terkait

4. Hasil kajian tim pengkajian lokasi ibukota Kabupaten Bima yang telah mengakomodir kriteria seperti yang disebutkan pada poin tiga (3) diatas kemudian diperkaya dengan kriteria tambahan sesuai aspirasi masyarakat dan kajian pustaka (20 kriteria) menunjukkan bahwa Kecamatan Woha memiliki nilai (Scoring) tertinggi, diikuti secara berturut-turut oleh Kecamatan Bolo, Sape, dan Belo. Sehingga secara teknis Kecamatan Woha dapat direkomendasikan sebagai alternatif terbaik sebagai lokasi Ibukota Kabupaten Bima.

5. Dari kriteria yang dipergunakan oleh tim pengkajian lokasi ibukota Kabupaten Bima disarankan agar kriteria hasil poling melalui Bima Ekspres tidak dimasukkan sebagai kriteria pengkajian, tetapi dipergunakan sebagai salah satu bahan pertimbangan dalam rangka penetapan lokasi ibukota Kabupaten Bima.

6. Untuk memperoleh feedback yang lebih luas dari masyarakat guna penyempurnaan hasil kajian lokasi ibukota Kabupaten Bima, tim kajian lokasi ibukota Kabupaten Bima masih menerima koreksi, masukan, saran, serta pertimbangan dari berbagai kalangan sampai dengan 20 juni 2006.

7. Sesuai dengan pasal 7 undangundang nomor 32 tahun 2004 tentang pemerintahan daerah maka untuk penetapan Kecamatan Woha sebagai 
ibukota Kabupaten Bima perlu segera ditindaklanjuti dengan persetujuan bersama antara Bupati dan DPRD Kabupaten Bima dan selanjutnya diusulkan kepada Gubernur Provinsi Nusa Tenggara Barat dan di teruskan ke Departemen Dalam Negeri agar dapat diproses lebih lanjut sehingga dapat ditetapkan dengan peratiran pemerintah (PP)

\section{Faktor Kependudukan.}

Faktor kependudukan adalah faktor pendukung yang bisa membantu percepatan pemindahan pusat Ibukota Kabupaten Bima, ranah penduduk berarti membicarakan tentang sumber daya manusia (SDM) dukungan moril dari masyarakat dapat meningkatkan semangat membangun bagi pemerintah daerah dalam proses pemindahan pusat Ibukota Kabupaten Bima yang administrasi sudah dilaksakan faktor kependudukan suatu lokasi pusat ibukota juga menjadi penentu dalam keberhasilan suatu kebijakan pemerintah yang dimaksud faktor penduduk ialah yang mencakup tentang jumlah penduduk yang ada di lokasi baru dan kota-kota sekitar untuk mengetahui potensi interaksi yang akan terjadi selanjutnya adalah seberapa besar pengaruh mata pencaharian penduduk di lokasi pusat pemerintahan baru dan sebarapa besar dukungan Heterogenitas penduduk dari segi suku. agama, dan etnis di sekitar wilayah pusat pemerintahannya.

Pemindahan pusat pelayanan pemerintahan ibukota Kabupaten Bima menjadi suatu kebanggan tersendiri bagi masyarakat Kabupaten Bima karena bagi masyarakat pelayanan yang baik adalah pelayanan yang dekat dengan masyarakat hal ini di dukung dari bukti wawancara dengan bapak Chandra selaku CAMAT Kecamatan Woha pada hari jum'at tanggal 13 April 2018 jam 14:00 beliau berangapan bahwa :

"saya sangat setuju dan mendukung pemindahan pusat ibukota Kabupaten Bima di Kecamatan Woha ini, begitu juga dengan masyarakat pada umumnya."

Dari hasil wawancara dengan bapak Chandra selaku CAMAT Kecamatan Woha dapat di tarik analisis bahwa pemindahan pusat pelayanan pemerintah Kabupaten Bima pada umumnya mendorong dan mendukung kehadiran Pemerintah Daerah Kabupaten Bima sebab masyarakat juga akan bangga akan kehadiran Pemerintah Daerah tersebut, pengaruhnya sangat besar terhadap sektor ekonomi masyarakat perputaran ekonomi semakin meningkat, usaha-usaha baru akan hadir.. 
Jadi, jika berbicara mengenai hubungan pemindahan pusat ibukota Kabupaten Bima dengan faktor kependudukan bahwa pada umumnya seluruh masyarakat sudah menerima dengan baik pemindahan pusat ibukota Kabupaten Bima di wilayah Kecamatan Woha, namun yang menjadi polemiknya adalah masyarakat sangat menyayangkan pemindahan pusat ibukota Kabupaten atau pusat pelayanan masyarakat tak kunjung disegerakan, yang dimana penduduk mendesak pemeintah Kabupaten Bima untuk sesegera mungkin kantor Bupati itu untuk segera pindah. Karena jika kantor Bupati atau seketariat Pemeritah Kabupaten Bima itu pindah maka. Masyarakat sangat merasa senang dan gembira pemimpin daerahnya semakin dekat dengan masyarakatnya.

3. Faktor Kebijakan Pemerintah.

Komitmen pemerintah terhadap pemindahan pusat ibukota Kabupaten Bima jika benar pusat pelayanan pemerintah itu di rancang dan tertuang di dalam Rencana Pembangunan Jangka Panjang Daerah (RPJPD) atau Rencana Pembangunan Jangka Menengah Daerah (RPJMD) dan selanjutnya tentang zona tata ruang yang mendukung apakah memungkinkannya kebijakan pemindahan pusat pelayanan pemerintahan di lokasi tersebut. Dari hasil wawancara dengan bapak A.rifaid selaku Kabid Tata Ruang Dinas Pekerjaan Umum dan Penataan Ruang pada hari senin, tanggal 2 April 2018 jam 11:00 mengatakan bahwa :

"Pemindahan pusat ibukota Kabupaten Bima sudah menjadi ranah kebijakan dari pemerintah Kabupaten Bima sejak dulu, dan pada tahun 2010 pemerintah Kabupaten Bima menfokuskan pada pembebasan lahan masyarakat, Seketariat atau kantor bupati mestinya di tahun 2015, dan di janjikan kembali di tahun 2018 mendatang."

Dari hasil wawancara dengan Bapak A.Rifaid selaku Kabid Tata Ruang Dinas Pekerjaan Umum dan Penataan Ruang dapat di analisis bahwa memang sejak pada tahun 2002 terjadi pemekaran Kota Bima dari induk Kabupaten Bima, namun pembangunan infrastruktur dimulai pada tahun 2014 dan akan diselesaikan sesuai target dengan Rencana Pembangunan Jangka Panjang Daerah RPJPD tahun 2006-2025 dan setiap tahunnya.

Pemerintah Kabupaten Bima berkonsisten membangun tiga (tiga) Organisasi Pemerintahan Deaerah (OPD) saja dari dana APBD maupun bantuan dana dari APBN maupun bantuan dari Provinsi. Dalam suatu kebijakan pembangunan wilayah pemerintah pada umumnya membuat suatu perencanaan 
yang mendetail yang di kenal dengan Rencana Detail Tata Ruang atau di singkat (RDTR) dan Peraturan Zonasi Kawasan Perkotaan serta Rencana Tata Ruang Wilayah atau di singkat (RTRW) kawasan perkotaan Woha pada Tahun 2014-2034.

\section{Faktor Politik}

Faktor politik merupakan salah satu faktor yang dapat menentukan kebijaakan pemindahan pusat pelayanan ibukota Kabupaten Bima. Jika kita melirik beberapa kasus contoh di Indonesia menyiratkan bahwa kontribusi elit politik atau sang penguasa menjadi faktor dominan yang menentukan arah laju suatu kebijakan kepentingan politik suatu golongan dalam mencapai pemindahan pusat ibukota. Selanjutnya megenai visi dan misi kepala daerah Kabupaten Bima, dalam hal ini adalah Bupati menjadi pengambilan kepetusan akhir dalam sebuah kebijakan-kebijakan yang di ambil. Berdasarkan hasil wawancara dengan bapak Bahrain selaku Kepala Bagian Organisasi Pendayagunaan Aparatur (OPA) Kabupaten Bima beliau mengatakan bahwa :

"Dalam hal kebijakan faktor politik Pemindahan pusat ibukota Kabupaten bima menjadi hak progratif dari kepala daerah yaitu BUPATI."

Dari hasil wawancara dengan bapak Bahrain selaku Kepala Bagian
Organisasi Pendayagunaan Aparatur (OPA) Kabupaten Bima dapat di analisis bahwa percepatan pemindahan atau keterlamatan pemindahan pusat Ibukota Kabupaten Bima menjadi keputusan hak Kepala Daerah, seluruh instansi-instansi yang berada di ruang lingkup Kabupaten Bima yang saat ini berada di wilayah Kota Bima sepenuhnya sudah siap untuk pindah kalau infrastruktur kantor yang disiapkan di lokasi pemindahan pusat ibukota Kabupaten Bima yang berada di Kecamatan Woha.

Mengenai isu politik bahwa keterlambatan pemindahan pusat ibukota Kabupaten Bima atau lebih tepatnya saat ini kantor seketariat atau kantor BUPATI itu disebabkan oleh ASN atau PNS yang kebanyakan masih berdomisili di Kota Bima dan tidak bersedia pindah ke lokasi pusat pelayanan ibukota Kabupaten Bima yang baru yang jaraknya tidak relatif dekat artinya jauh dari Kota Bima.

Jadi, jika berbicara mengenai hubungan Pemindahan pusat Ibukota Kabupaten Bima dengan faktor politik bahwa tidak ada indikasi politik dari elitelit politik terhadap perhambatan pemindahan pusat ibukota Kabupaten Bima itu sendiri. Jika melirik pembangunan pusat pemrintahan Kabupaten Bima sedang dalam proses pembangunan, pemerintah Kabupaten 
Bima menghimbau dan berharap kepada seluruh masyarakat Kabupaten Bima untuk bisa bersabar dan selalu mensuport proses pemindahan pusat ibukota kabupaten Bima yang saat ini dalam proses laju pembangunan.

\section{Faktor Historis}

Terbentuknya Kota Bima berasal dari sebagian wilayah Kabupaten Bima yang antara lain Raba termasuk dalam wilayah Kota Bima. Dengan masuknya Raba menjadi bagian dari Kota Bima maka ibu kota Kabupaten Bima yang berlokasi di Raba wilayah Kota Bima perlu dipindah ke wilayah Kabupaten Bima. Dan hasil kajian yang dilakukan oleh Pemerintah Kabupaten Bima, serta sesuai dengan aspirasi masyarakat Kabupaten Bima, Kecamatan Woha layak untuk dijadikan ibu kota Kabupaten Bima, karena semangat mendukung pengembangan ke masa depan, aksesibilitas, rentang kendali pemerintahan, dan dukungan lahan.

Pemindahan ibu kota kabupaten dari Raba wilayah Kota Bima ke Kecamatan Woha Kabupaten Bima telah diusulkan oleh Bupati Bima kepada DPRD Kabupaten Bima dengan Surat Nomor 135/091/001/BAPPEDA tanggal 8 Agustus 2006 perihal Persetujuan Penetapan Lokasi Ibukota Kabupaten Bima, telah mendapat persetujuan dari DPRD Kabupaten Bima berdasarkan
Keputusan Nomor 24 Tahun 2006 tanggal 9 November 2006 tentang Persetujuan Penetapan Ibukota Kabupaten Bima.

Berdasarkan persetujuan DPRD Kabupaten Bima tersebut, Bupati Bima sudah mengajukan permohonan kepada Gubernur NTB dengan surat Nomor 135/056/PEM/2007 tanggal 23 Mei 2007 perihal permohonan pemindahan dan penetapan lokasi ibukota Kabupaten Bima dan kemudian Gubernur Nusa Tenggara Barat dengan surat Nomor 125/661/Pem tanggal 29 Juni 2007 mengajukan kepada Menteri Dalam Negeri untuk memohon pemindahan dan penetapan lokasi ibu kota Kabupaten Bima. Dari hasil wawancara dengan bapak Bahrain selaku Kabag. Organisasi Pendayagunaan Aparatur Kabupaten Bima beliau mengatakatan bahwa :

"Sejarah pemindahan pusat Ibukota Kabupaten Bima sudah melalui tahapan-tahapan yang panjang, semua masalah perijinan-perijinan sudah dilalui oleh pemerintah Kabupaten Bima, sekarang tinggal bagaimana saja laju percepatan pembangunan bisa di tingkatkan lagi."

Dari hasil wawancara dengan Bapak Bahrain selaku Kabag. Organisasi Pendayagunaan Aparatur Kabupaten Bima dalam kalkulasi usia, Kabupaten Bima telah melintasi perjalanan sejarah yang 
amat panjang. Bahkan mengalami masamasa timbul tenggelam yang dalam perspektif ilmu negara disebut teori timbul tenggelamnya negara. Menurut teori kekuasaan bahwa negara terbentuk karena kekuasaan. Orang kuatlah yang pertamatama mendirikan negara, karena dengan kekuatannya itu ia berkuasa memaksakan kehendaknya terhadap orang lain sebagaimana dikemukakan Kallikles dan Votaire bahwa raja yang pertama adalah prajurit yang berhasil.

Begitu juga teori tenggelamnya negara seperti teori organis, teori anarkis, dan teori Marxis yang memandang bahwa negara adalah sebuah organisme dan tata paksa baik dengan kekerasan maupun tidak yang pada akhirnya akan hilang dengan sendirinya menurut syarat-syarat obyektifnya sendiri. Timbul tenggelamnya Kabupaten Bima terungkap dalam naskah kuno yang dimiliki Kerajaan Bima, Bo Sangaji Kai.

\section{PENUTUP}

Dalam pengimplemantasian pemindahan pusat ibukota dan pembangunan ibukota Kabupaten Bima di lokasi yang baru sedang dalam proses pembangunan insfrastruktur dari 43 Organisasi Perangkat Daerah hanya 6 OPD yang sudah berada pada lokasi pusat pelayanan pemerintah Kabupaten Bima diantara yaitu : Dinas Kependudukan dan
Catatan Sipil, Dinas Pendidikan, Kebudayaan, Pemuda dan Olahraga, Satuan Polisi Pamong Praja, Dinas Perhubungan, Badan Penanggulangan Bencana Daerah serta Dinas Perumahan dan Kawasan Pemukiman.

Dari latar belakang pemindahan pusat ibukota Kabupaten Bima yang melatar belakangi penghambatan pemindahan pusat ibukota Kabupaten Bima adalah faktor anggaran, dimana dana yang digunakan dalam pembangunan infrastruktur adalah hanya bersumber dari APBD. Dari kelima (5) faktor yang mempengaruhi pemindahan ibukota Kabupaten Bima yaitu faktor letak geografis, faktor kependudukan, faktor kebijakan pemerintah, faktor politik dan faktor historis/sejarah sudah berjalan dengan baik artinya mendukung dan mempengaruhi percepatan pemindahan pusat ibukota Kabupaten Bima.

Hanya saja faktor penduduk atau dari masyarakat mengharapkan dan mendesak pemerintah kabupaten untuk sesegera mungkin percepatan pemindahan pusat ibukota Kabupaten Bima, agar tercapai pelayanan yang cepat dan tepat.

Saran yang dapat di berikan oleh penulis adalah Pemerintah Kabupaten Bima harus lebih meningkatkan percepatan pembangunan insfrastruktur kantor yang awalnya hanya 3 Organisasi 
perangkat daerah pertahunya, bisa di tingkatkan lagi lebih dari 3 pertahunya. Organisasi Perangkat Deaerah sehingga jangka waktu pembangunan infrastruktur tidak relatif lama.

\section{DAFTAR PUSTAKA}

Ali, M.F.U.2010. Evaluasi Lokasi Pusat Pemerintahan Kabupaten Halmahera Tengah. Tesis.

Ahmad dan Abdul Hamid. 2008 . Lembaga Keuangan Syariah : PT. Bestari Buana Murni.

Claval, P. 2000. The European System of Capital Cities. Geo Jurnal 51 (1/2), $73-81$.

HR, Ridwan. 2014. Hukum Administrasi Negara Edisi Revisi. Jakarta : PT. Raja Grafindo Persada.

Margono, 1997. Metodologi Penelitian Penddikan. Jakarta. Rineka Cipta.

Michigan Lean Consortium. 2013. State of Michigan: Good Government Initiative (internet). http://michiganlean.org/page1356647 (diakses 27 Oktober 2017)

Myoe, M.A. 2006. The Road to Naypyitaw : Making Sense of The Myanmar Government's Decision to Move its Capital. Asia Research Institute National University of Singapore 79 (-), 1-19.

Qi, D. 2008. Early Capital Cities- The Key Simbol of Early Chinese Civilization. Front.Hist.China 3 (1), 1 - 11.

Rieseneder,F.B.2008. Good Governance: Characteristics, Methods, and The Austrian examples. Transylvanian Review of Administrative Sciences 24 (E), 26-52.

Rustiadi, dkk. 2009. Perencanaan dan Pengembangan Wilayah. Jakarta: Yayasan Obor Indonesia

Sadjijono, 2008, Memahami Beberapa Bab Pokok Hukum
Administrasi,Laksbang Pressindo, Yogjakarta, hal. 41

Siong, H.C. 2006. PutrajayaAdministrative of Malaysia : Planning, Concept, and Implementation. Suistainable Urban Development and Governance Conference SungKyunKwan University Seoul.

S.H. Sarundajang, 2003. Birokrasi Dalam Otonomi Daerah, Upaya Mengatasi Kegagalannya.

Syarif, A. 2013. Faktor-Faktor yang Mempengaruhi Perkembangan Fisik Kota Baubau.Tesis: Universitas Gadjah Mada.

Tarigan, R. 2006. Perencanaan Pembangunan Wilayah . Edisi Revisi. Penerbit: PT. Bumi Aksara.

Tukiyat. 2002. Pengembangan Wilayah dan Otonomi Daerah. Bab 6: Pengantar Pengembangan Ekonomi Wilayah. Jakarta: BPPT.

Wusten, HVD.2000. The Cityscape of European Capital Cities. GeoJurnal $51(-), 129-133$.

Peraturan Perundang-undangan :

UU Nomor 13 Tahun 2002 Tentang Pembentukan Kota Bima Di Provinsi Nusa Tenggara Barat

Undang-Undang Republik Indonesia Nomor 23 Tahun 2014 Tentang Pemerintahan Daerah

Peraturan Pemerintah Nomor 129 Tahun 2000 Tentang Persyaratan Pembentukan Dan Kriteria Pemekaran, Penghapusan Dan Penggabungan Daerah

Peraturan Pemerintah Republik Indonesia Nomor 31 Tahun 2008 Tentang Pemindahan Ibu Kota Kabupaten Bima Dari Raba Wilayah Kota Bima Ke Kecamatan Woha Kabupaten Bima

Peraturan Pemerintah No 78 Tahun 2007 Tentang Pembentukan, Penghapusan, Dan Penggabungan Daerah. 